\title{
MODEL MANAJEMEN PERSEDIAAN DAN KONTROL KEMIKALIA DI LABORATORIUM KIMIA FAKULTAS MATEMATIKA DAN ILMU PENGETAHUAN ALAM UNIVERSITAS JENDERAL SOEDIRMAN
}

\author{
Wuryatmo A. Sidik ${ }^{1}$, Sunardi ${ }^{2}$, Supriyanto ${ }^{3}$
}

\begin{abstract}
Abstrak: Kemikalia merupakan benda yang sangat penting dalam operational enam laboratorium di lingkungan jurusan Kimia Fakultas Matematika dan Ilmu Pengetahuan Alam (FMIPA) Universitas Jenderal Soedirman (UNSOED). Kemikalia bersifat reaktif dan mempunyai masa kadaluwarsa. Oleh karena itu ketua laboratorium dan laboran harus memantau secara ketat jumlah dan kondisi semua semua persediaan kemikalia di laboratoriumnya. Makalah ini menyajikan suatu model manajemen persediaan dan pengendalian persediaan kemikalia yang dapat memenuhi kebutuhan kemikalia di semua laboratorium yang ada dengan biaya yang paling murah serta mengurangi jumlah kemikalia yang kadaluwarsa.
\end{abstract}

Kata kunci: Model; Manajemen; Persediaan; Control; Kemikalia

\begin{abstract}
Chemicals are very important items in the operational of six laboratories in the Department of Chemistry, Faculty of Mathematics and Natural Sciences (FMIPA) Universitas Jenderal Soedirman (UNSOED). Chemicals are reactive and have expired date. Thus the head and assistant of laboratory must closely monitor the number and condition of all the chemicals in the laboratory. This paper presents a model of inventory management and chemical control that can meet the needs of chemicals with the lowest cost and reduce the number of expired chemicals.
\end{abstract}

Keywords: Model; Inventory; Management; Control; Chemical

\section{PENDAHULUAN}

Laboratorium di lingkungan Jurusan Kimia Fakultas Matematika dan Ilmu Pengertahuan Alam (FMIPA) Universitas Jenderal Soedirman (UNSOED) merupakan ujung tombak pengembangan pembelajaran (praktikum) dan penelitian dan layanan analisa. Ada 6 laboratorium di jurusan Kima FMIPA yaitu Lab. Kimia Dasar, Lab. Kimia Fisik, Lab. Biokimia, Lab. Kimia Analitik, Lab. Kimia Anorganik, dan Lab. Kimia Organik.

Kemikalia merupakan benda yang sangat penting dalam operasional ke enam laboratorium tersebut. Jenis dan jumlah kemikalia yang dibutuhkan oleh masing-masing laboratorium bervariasi, namun sifat yang dimiliki sama tergantung pada waktu karena semua kemikalia mempunyai masa kadaluwarsa. Dengan demikian ketua laboratorium dan laboran harus memantau secara ketat jumlah dan kondisi semua semua persediaan kemikalia di laboratorium serta mengetahui jadwal untuk melakukan pemesanan kembali.

Melalui observasi lapangan yang telah penulis lakukan, diperoleh fakta bahwa sering terjadi kelangkaan beberapa jenis kemikalia, namun banyak juga kemikalia lainya yang kedaluarsa 
menumpuk di gudang. Hal ini menunjukkan bahwa proses pengadaan kemikalia tidak efisien dan terjadi pemborosan. Makalah ini menyajikan suatu model manajemen persediaan dan pengendalian persediaan kemikalia yang dapat memenuhi kebutuhan kemikalia semua laboratorium dilingkungan jurusan Kimia FMIPA UNSOED dengan biaya yang paling murah serta mengurangi jumlah kemikalia yang kadaluwarsa.

\section{METODE}

Kemikalia merupakan zat reaktif dan mudah kadaluwarsa sehingga dalam pengadaan, penyimpanan, penggunaan dan penghapusan perlu perhitungan secara matang. Dalam membuat model persediaan dan pengendalian kemikalia harus mempertimbangkan sejumlah faktor. Model harus dirancang sedemikian rupa sehingga laboratorium dapat memantau secara ketat kondisi semua persediaan kemikalia, jumlah yang tersedia serta memberi peringatan ketika ada kebutuhan untuk menyusun ulang. Permohonan pengadaan kemikalia diajukan oleh laboratorium lewat jurusan ke fakultas. Pengadaan dilakukan oleh fakultas melalui rekanan (supplier). Pada umumnya kemikalia mempunyai masa kadaluwarsa yang cepat sehingga pihak supplier memberi tawaran diskon untuk kemikalia yang mempunyai masa kadaluwarsa atau pembelian partai banyak. Hal ini dapat menimbulkan pemesanan yang tidak dibutuhkan oleh laboratorium. Dengan kata lain, sebenarnya belum tepat waktunya untuk melakukan pemesanan kemikalia tetapi karena adanya tawaran diskon dari supplier menyebabkan bagian pengadaan fakultas memilih untuk mengambil tawaran diskon itu padahal pihak logistik laboratorium belum membutuhkan kemikalia tersebut. Besarnya diskon yang diberikan juga berbeda-beda tergantung dari manajemen dan kerjasama fakultas dengan perusahaan kemikalia. Meskipun supplier memberikan diskon pada kuantitas tertentu, jika jadwal pembelian kemikalia tidak teratur maka akan menyebabkan pembengkakan biaya persediaan (Adhikari, S. R, 2011). Setelah melakukan pemesanan kemikalia, ada kemungkinan penerimaan barang tidak serentak yang disebabkan oleh terbatasnya kemampuan produksi, distribusi, atau transportasi dari pihak supplier (El-Sodany, N. H, 2011).

\section{HASIL DAN PEMBAHASAN}

\section{Model Persediaan dan Pengendalian Kemikalia FMIPA UNSOED}

Karakteristik dari permasalahan pengadaan dan penyimpanan kemikalia antara lain:

- Permintaan kemikalia bersifat non-konstan dan tidak dapat dilakukan peramalan terhadap suatu kebutuhan praktikum dan analisa

- Harga kemikalia berubah tergantung diskon yang diberikan.

- Harga kemikalia konstan dan tidak tergantung pada jumlah yang dipesan dan waktu pemesanan.

- Biaya simpan konstan tidak tergantung pada jumlah bahan yang disimpan.

- Biaya jika terjadi kekurangan akan sebanding dengan jumlah kemikalia yang kurang.

- Masa tunggu (lead time) pemesanan kemikalia diketahui dan konstan.

- Masa kadaluwarsa kemikalia diketahui dengan pasti

- Seluruh bahan yang kadaluwarsa memerlukan biaya simpan dan biaya pemusnahan. 
- Kekurangan kemikalia akan terjadi ketika kemikalia sudah melewati masa kadaluwarsa atau kehabisan persediaan digudang.

Biaya (cost) yang diperhitungkan dalam model meliputi biaya pemesanan, biaya pembelian, dan biaya penyimpanan, biaya kadaluwarsa dan biaya pemusnahan. Biaya Pemesanan (Order Cost) merupakan biaya yang dikeluarkan ketika sebuah pesanan akan dilakukan ke supplier (Kelle, P., Woosley, J., dan Schneider, H, 2012). Dimana setiap melakukan pemesanan akan dikenakan biaya pesan yang bisa berubah tergantung periode pemesanan. Biaya pemesanan diperoleh melalui perkalian antara biaya sekali pesan dengan frekuensi pesan dalam setahun yang dituliskan pada Persamaan 1.

$C_{o}=\sum \frac{D}{T_{s}} C_{o j}$

Biaya Pembelian (Purchase Cost) adalah biaya yang dikeluarkan untuk membeli bahan baku j. Dimana harga pembelian tergantung dari faktor diskon yang diberikan oleh supplier tetapi jumlah diskon yang diberikan tidak tergantung pada jumlah bahan $j$ yang akan dibeli. Biaya Pembelian merupakan jumlah kebutuhan (demand) kemikalia $j$ yang dibeli pada saat siklus $t$ yang dikalikan dengan harga per-unit kemikalia $j$ dengan diskon $i$, yang dituliskan pada persamaan berikut:

$C_{p}=\sum D_{j} C_{o j}$

Biaya penyimpanan (bolding cost) adalah biaya yang dikeluarkan ketika ada sejumlah kemikalia $j$ yang disimpan sehingga diperlukan pemeliharaan, sewa gudang, biaya asuransi bahan dan biaya listrik (El-Sodany, N.H, 2011). Dalam kasus ini, biaya simpan hanya terdiri dari asuransi dan interest rate saja. Biaya Penyimpanan merupakan perkalian antara harga penyimpanan per unit kemikalia $j$ dengan rata-rata jumlah bahan yang disimpan dan lama waktu penyimpanan seperti yang terdapat pada Persamaan 3.

$C_{h}=\sum \quad C_{h j}\left(\frac{2 Q_{j t}-\frac{D_{i j t} T_{1 j}}{T_{S}}}{2}\right) T_{1 j}$

Biaya Kekurangan (Stockout Cost) adalah biaya yang dikeluarkan akibat jumlah persediaan bahan $\mathrm{j}$ habis atau ketika ada bahan $j$ digudang tetapi sudah kadaluwarsa. Biaya Kekurangan merupakan perkalian antara harga kekurangan per unit bahan $j$ dengan jumlah kekurangan bahan dan lama waktu terjadi kekurangan

$$
C_{s}=\sum \quad C_{p i j} D_{j t}\left(\frac{T_{s}-T_{1 j}}{T_{s}}\right)
$$

Biaya Kadaluwarsa (Expired Cost) adalah biaya yang dikeluarkan akibat bahan $\mathrm{j}$ yang disimpan telah melewati masa pakai (Adhikari, S. R, 2011; Tersine, R. J, 1994). Dalam penelitian ini, bahan yang sudah kadaluwarsa tidak langsung dimusnahkan sehingga menimbulkan biaya penyimpanan dan biaya pemusnahan. 
Biaya Kadaluwarsa merupakan perkalian jumlah barang yang kadaluwarsa dengan harga jual bahan setelah kadaluwarsa dan jumlah siklus dalam setahun (Persamaan 5).

$$
C_{e}=\sum \quad\left(Q_{j t}-\frac{D_{j t} T_{1 j}}{T_{s}}\right) J_{j} \frac{D_{j}}{Q_{j t}}
$$

Biaya pemusnahan adalah biaya yang dikeluarkan ketika ada sejumlah bahan $j$ yang harus dimusnahkan. Biaya Pemusnahan merupakan biaya pemusnahan per unit bahan $j$ dikali dengan frekuensi pemusnahan pertahun.

$C_{x}=\sum \frac{D}{T_{s}} C_{x j}$

Sehingga pengadaan kemikalia akan optimum jika

$\begin{array}{ll}C_{T}=\sum \frac{D}{T_{s}} C_{o j}+\sum D_{j} C_{p i j}+\sum & C_{h j}\left(\frac{2 Q_{j t}-\frac{D_{i j t} T_{1 j}}{T_{S}}}{2}\right) T_{1 j}+\sum \quad C_{p i j} D_{j t}\left(\frac{T_{s}-T_{1 j}}{T_{s}}\right)+\sum \quad\left(Q_{j t}-\right. \\ \left.\frac{D_{j t} T_{1 j}}{T_{S}}\right) J_{j} \frac{D_{j}}{Q_{j t}}+\sum \frac{D}{T_{s}} C_{x j} & \ldots \ldots \ldots \ldots(7)\end{array}$

\section{DAFTAR PUSTAKA}

Adhikari, S. R. A Methodological Review of Demand Analysis: An Example of Health Care.

El-Sodany, N. H. (2011). Periodic Review Probabilistic Multi-Item Inventory System with Zero Lead Time Under Constraint and Varying Holding Cost. Journal of Mathematics and Statistics, 7(1), 12-19.

Kelle, P., Woosley, J., dan Schneider, H. (2012). Pharmaceutical Supply Chain Specifics and Inventory Solutions for A Hospital Case, Operations Research for Health Care, 1, 54-63.

Services. (2012). Economic Journal of Development Issues, 13-14(1-2), 119-130.

Tersine, R. J. (1994). Principles of Inventory and Materials Management $4^{\text {th }}$ Edition. New Jersey: Prentice Hall Inc. 